University of Nebraska - Lincoln

DigitalCommons@University of Nebraska - Lincoln

Agronomy \& Horticulture -- Faculty Publications

Agronomy and Horticulture Department

2011

No-tillage increases soil profile carbon and nitrogen under longterm rainfed cropping systems

Gary E. Varvel

University of Nebraska-Lincoln, gevarvel@windstream.net

Wallace Wilhelm

University of Nebraska-Lincoln, wwilhelm1@unl.edu

Follow this and additional works at: https://digitalcommons.unl.edu/agronomyfacpub

Part of the Plant Sciences Commons

Varvel, Gary E. and Wilhelm, Wallace, "No-tillage increases soil profile carbon and nitrogen under longterm rainfed cropping systems" (2011). Agronomy \& Horticulture -- Faculty Publications. 591.

https://digitalcommons.unl.edu/agronomyfacpub/591

This Article is brought to you for free and open access by the Agronomy and Horticulture Department at DigitalCommons@University of Nebraska - Lincoln. It has been accepted for inclusion in Agronomy \& Horticulture -Faculty Publications by an authorized administrator of DigitalCommons@University of Nebraska - Lincoln. 


\title{
No-tillage increases soil profile carbon and nitrogen under long-term rainfed cropping systems
}

\author{
G.E. Varvel ${ }^{*}$, W.W. Wilhelm ${ }^{1}$ \\ USDA-Agricultural Research Service and Department of Agronomy, University of Nebraska, Lincoln, NE 68583, United States
}

\section{A R T I C L E I N F O}

\section{Article history:}

Received 20 September 2010

Received in revised form 21 March 2011

Accepted 22 March 2011

Available online 22 April 2011

\section{Keywords:}

Soil organic carbon

Soil nitrogen

Tillage

Cropping systems

\begin{abstract}
A B S T R A C T
Emphasis and interest in carbon (C) and nitrogen (N) storage (sequestration) in soils has greatly increased in the last few years, especially $C$ with its' potential to help alleviate or offset some of the negative effects of the increase in greenhouse gases in the atmosphere. Several questions still exist with regard to what management practices optimize $C$ storage in the soil profile. A long-term rainfed study conducted in eastern Nebraska provided the opportunity to determine both the effects of different tillage treatments and cropping systems on soil $\mathrm{N}$ and soil organic $\mathrm{C}(\mathrm{SOC})$ levels throughout the soil profile. The study included six primary tillage systems (chisel, disk, plow, no-till, ridge-till, and subtill) with three cropping systems [continuous corn (CC), continuous soybean (CSB), and soybean-corn (SB-C)]. Soil samples were collected to a depth of 150-cm in depth increments of 0-15-, 15-30-, 15-30-, 30-60-, 6090-, 90-120-, and 120-150-cm increments and composited by depth in the fall of 1999 after harvest and analyzed for total $\mathrm{N}$ and SOC. Significant differences in total $\mathrm{N}$ and SOC levels were obtained between tillage treatments and cropping systems in both surface depths of $0-15-, 15-30-\mathrm{cm}$, but also in the $30-$ $60-\mathrm{cm}$ depth. Total $\mathrm{N}$ and SOC accumulations throughout the profile (both calculated by depth and for equivalent masses of soil) were significantly affected by both tillage treatment and cropping system, with those in no-till the greatest among tillage treatments and those in CC the greatest among cropping systems. Soil N and SOC levels were increased at deeper depths in the profile, especially in those tillage systems with the least amount of soil disturbance. Most significant was the fact that soil N and SOC was sequestered deeper in the profile, which would strongly suggest that $\mathrm{N}$ and $\mathrm{C}$ at these depths would be less likely to be lost if the soil was tilled.
\end{abstract}

Published by Elsevier B.V.

\section{Introduction}

Advantages of using conservation tillage systems include water conservation, reduced production costs, reduced wind and water erosion, recycling of crop residues and their nutrients, and increased yields. Accordingly, these attributes have increased the adoption of conservation tillage systems throughout the U.S. According to Towery and Werblow (2010), approximately $42 \%$ of the US cropland is using some form of conservation tillage.

More recently, conservation tillage was identified in recent literature reviews by Johnson et al. (2006b) and Wilhelm et al. (2007) as being necessary if producers hope to increase or maintain soil organic carbon (SOC) levels. West and Post (2002) concluded in their extensive review of results from 67 long-term experiments

\footnotetext{
* Corresponding author at: USDA-ARS-AEMRU, University of Nebraska, 129 Kiem Hall, East Campus, Lincoln, NE 68583-0937, United States.

E-mail address: Gary.Varvel@ars.usda.gov (G.E. Varvel).

${ }^{1}$ Deceased. Joint contribution of USDA-ARS and the Nebr. Agric. Res. Div. Received.
}

from around the world that when management was changed from conventional tillage to a no-till system, a significant increase in SOC was obtained, but in their analysis they found approximately $85 \%$ of that change occurred in the surface $7-\mathrm{cm}$ of soil. It is also important to note that only six of their 276 paired comparisons were from sampling depths greater than $30-\mathrm{cm}$. West and Post (2002) also noted that increased cropping diversity appeared to increase SOC levels, but these increases were not as much as those obtained from utilization of some form of reduced or no-till system. Recent reports by Pikul et al. (2008) and Varvel (2006) from long-term conventionally tilled experiments indicated similar results to those of West and Post (2002) in that even with increased cropping diversity, SOC levels were reduced or at best maintained in the surface $30-\mathrm{cm}$ after $15-20$ years.

Most if not all the results reported above are related to SOC levels in the surface $0-15-\mathrm{cm}$ depth of soils. Increased SOC is very important as it affects many soil properties including aggregate stability, water holding capacity, cation exchange capacity, nutrient cycling, and many others factors critical to soil function. Sparling et al. (2006) noted that crop yield and environmental services ( $\mathrm{C}$ and $\mathrm{N}$ sequestration) were greater for soils with greater 
SOC levels. Brejda et al. (2000) also identified SOC as one of the most sensitive indicators of soil quality in the Central and Southern High Plains.

Increases in soil $\mathrm{N}$ and $\mathrm{SOC}$ are not restricted to the $0-15-\mathrm{cm}$ depth of soil. Increasing soil $\mathrm{N}$ and SOC levels can also greatly benefit these same soil properties at deeper depths in the profile, where SOC may actually be stored in more stable forms (Angers and Eriksen-Hamel, 2008). Documenting increased SOC levels at deeper depths in the soil profile, however, has been difficult due to a lack of studies where sampling occurred below $30 \mathrm{~cm}$. In recent publications, several researchers have reported results that question whether reduced or specifically no-till systems actually are increasing SOC levels anywhere but in the surface soil layers. Angers and Eriksen-Hamel (2008) found in their review of the literature where SOC profiles were measured to depths of at least $30-\mathrm{cm}$ in studies directly comparing no-till and full-inversion tillage (FIT) for $>5$-yr that SOC content was significantly greater under no-till than FIT in the surface soil layers $(0$ to $\sim 5-10 \mathrm{~cm})$. Their review also found that at the $21-25-\mathrm{cm}$ soil depth the average SOC content was significantly greater under FIT than notill, which corresponded to the average plowing depth for their data set from the literature. Gal et al. (2007) also reported similar results from a long-term crop and tillage system study conducted in Indiana where no-till and plow (FIT) tillage systems were compared. Their results indicated that as reported above, total $\mathrm{N}$ and SOC levels were significantly greater in the surface depths for no-till, but when the full sampling depth (1-m) was considered, greater SOC under no-till was observed, but the difference was much less than in surface depths. Their recommendation was that tillage comparisons of total $\mathrm{N}$ and SOC accumulations should be based on samples taken below the deepest tillage depth.

As can be discerned from the discussion above, changes in soil organic matter take time. In most if not all of the studies referenced, the minimum amount of time that was of interest was $5 \mathrm{yr}$, but in most cases the study periods were much longer. This slow response to crop and soil management practices and the variable nature of SOC measurements requires a significant amount of time before the direction of change can be determined (Lal, 2004). Long-term (40-60-yr) increases in SOC will probably be caused by increased cropping system diversity and changes in residue inputs and composition (West and Post, 2002). It stands to reason that these same statements can also be made about changes in soil $\mathrm{N}$ with its' close relationship to soil $\mathrm{C}$ in organic matter, although much less information on soil $\mathrm{N}$ is presented in the literature.

In addition, as noted by concerns expressed above, it is important to evaluate changes in soil $\mathrm{N}$ and SOC not only in the surface soil layers, but also at deeper depths in the profile. First and foremost, these comparisons need to be made so that valid conclusions can be reached about both if and where in the soil profile crop and tillage systems are sequestering soil $\mathrm{N}$ and SOC. This opportunity existed in a long-term tillage and cropping system experiment conducted in eastern Nebraska for the past 20-30-yr. Our objective was to evaluate the long-term effects of tillage and crop management systems on total soil $\mathrm{N}$ and SOC throughout the profile in a rainfed experiment in the western Corn Belt.

\section{Materials and methods}

This experiment was initiated in 1980 at the Rogers Memorial Farm on a silty clay loam soil (deep, moderately well-drained upland Sharpsburg soil formed in loess; fine, smectitic, mesic Typic Argiudolls) approximately $19 \mathrm{~km}$ east of Lincoln, NE (latitude 40.843 , longitude 96.465 ) under natural rainfall conditions. The site had a mean average temperature (MAT) of $19.9{ }^{\circ} \mathrm{C}$ and mean average precipitation (MAP) of $708.1 \mathrm{~mm}$ from 1986 through 2001 according to Wilhelm and Wortmann (2004).

The experiment was originally designed as a randomized complete block (six replications) with six tillage treatments. Each of the six replications were originally arranged to be located on approximately the same landscape position to help reduce variability within the block. Tillage treatments were chisel plow (chisel), tandem disk (disk), moldboard plow (plow), no-till, ridgetill, and subsoil tillage (subtill). Corn (Zea mays L.) was the only crop in the experiment for the first 6-yr. The original design was then modified in 1986 to a randomized complete block design with a split-plot arrangement of cropping systems. Subplot treatments were continuous corn, continuous soybean [Glycine max (L.) Merr.], and a 2-year soybean-corn rotation with each phase present each year. Whole tillage plots were $18.3(24,0.76-\mathrm{m}$ rows $) \times 22.9 \mathrm{~m}$. Subplots were 4.6 (six, 0.76-m rows) $\times 22.9 \mathrm{~m}$.

After grain harvest from 1980 to 1999 , corn stover was chopped and the chisel, plow, and subsoil treatments were applied. Depth of tillage was approximately $25 \mathrm{~cm}$ for the chisel and plow treatments and $36 \mathrm{~cm}$ for the subsoil treatment. Chisel shanks with straight points at a $25-\mathrm{cm}$ spacing were used. The subsoil implement (Blu-jet Subtiller ${ }^{2}$, Thurston Manufacturing Company, Thurston, NE) was equipped with standard shanks and fall-till points at a 76- $\mathrm{cm}$ spacing and positioned to operate between the planted rows. Residue was chopped in spring for the disk, no-till, and ridge-till treatments. Depth of tillage for the disk treatment was approximately $10 \mathrm{~cm}$. All tilled treatments were disked to $<10 \mathrm{~cm}$ depth prior to planting (including the disk treatment, which was disked a second time). No primary or secondary preplant tillage operations were performed on the no-till or ridge-till treatments.

Corn was planted as weather and soil conditions allowed, usually in the first week of May. Soybean planting also depended on weather and soil conditions but was usually delayed by $1 \mathrm{wk}$ after corn was planted. All crops were planted in 76-cm rows with a planter equipped with six Kinze "Precision Placement, Style A" row units (Kinze Manufacturing Company, Williamsburg, IA) with double-disk openers. Scalloped trash disks were adjusted to remove $3-5 \mathrm{~cm}$ of soil from the top of the ridge in the ridge-till treatment. In the no-till treatment, the trash disks were adjusted to move $0-2 \mathrm{~cm}$ of soil and the old crown from the row. All treatments, except no-till, were cultivated between the V5 and V8 growth stages (Ritchie et al., 1986) for corn and about V5 growth stage (Ritchie et al., 1996) for soybean. At this time, or within 2 wk, ridges were formed in the ridge-till treatment. Both cultivating and ridging were done with a Buffalo row-crop cultivator (Fleischer Manufacturing Company, Columbus, NE).

Other cultural practices were similar to those used by local producers. Corn hybrids and soybean varieties planted each year were chosen from commercially available selections adapted to the area. Planting population for corn ranged from 40,000 kernels ha ${ }^{-1}$ in the early years of the study to 58,000 kernels ha ${ }^{-1}$ since 1996. Soybean was planted at rates between 250,000 and 375,000 seeds ha ${ }^{-1}$. Insecticides (which varied over years) were applied to corn at planting according to label procedures to reduce rootworm damage. For both corn and soybean, a combination of pre- and post-emergence herbicides (again, products varied over the years of study), cultivation, and hand weeding were used to control weeds. Roundup-Ready varieties of soybean have been planted since 1998. Roundup-Ready hybrids of corn have been planted since 1999. Nitrogen fertilizer was broadcast on corn only

\footnotetext{
${ }^{2}$ Product names are given solely for the benefit of the reader and are not meant to constitute a recommendation or warranty by the U.S. Department of Agriculture's Agricultural Research Service or the Agricultural Research Division of the University of Nebraska.
} 
Table 1

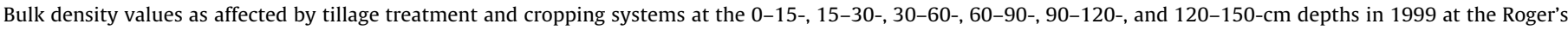
Memorial Farm near Lincoln, NE.

\begin{tabular}{|c|c|c|c|c|c|c|c|}
\hline \multirow[t]{3}{*}{ Tillage } & & \multicolumn{6}{|c|}{ Depth (cm) } \\
\hline & & $0-15$ & $15-30$ & $30-60$ & $60-90$ & $90-120$ & $120-150$ \\
\hline & & \multicolumn{6}{|c|}{$\rho_{\mathrm{b}}\left(\mathrm{Mg} \mathrm{m}^{-3}\right)$} \\
\hline Chisel & & 1.37 & 1.46 & 1.54 & 1.56 & 1.64 & 1.50 \\
\hline Disk & & 1.38 & 1.45 & 1.48 & 1.49 & 1.61 & 1.49 \\
\hline Plow & & 1.29 & 1.45 & 1.50 & 1.50 & 1.60 & 1.48 \\
\hline No-till & & 1.33 & 1.42 & 1.46 & 1.45 & 1.58 & 1.44 \\
\hline Ridge till & & 1.36 & 1.42 & 1.44 & 1.51 & 1.64 & 1.57 \\
\hline Subtill & & 1.35 & 1.42 & 1.46 & 1.51 & 1.59 & 1.52 \\
\hline \multirow[t]{6}{*}{ S.E. } & & 0.02 & 0.02 & 0.01 & 0.02 & 0.02 & 0.02 \\
\hline & \multicolumn{7}{|c|}{ Cropping system $^{\mathrm{a}}$} \\
\hline & $\mathrm{CC}$ & 1.35 & 1.44 & 1.50 & 1.52 & 1.60 & 1.48 \\
\hline & SB-C & 1.33 & 1.44 & 1.46 & 1.50 & 1.61 & 1.50 \\
\hline & CSB & 1.35 & 1.43 & 1.47 & 1.48 & 1.62 & 1.52 \\
\hline & S.E. & 0.01 & 0.01 & 0.01 & 0.01 & 0.02 & 0.02 \\
\hline Source of variation & df & \multicolumn{6}{|c|}{ Mean squares } \\
\hline Replication & 5 & 0.005 & 0.010 & $0.024^{* * * *}$ & $0.165^{* * *}$ & $0.054^{* * * *}$ & 0.016 \\
\hline Tillage (T) & 5 & 0.017 & 0.007 & $0.025^{* * *}$ & 0.020 & 0.013 & 0.034 \\
\hline Error (a) & 25 & 0.009 & 0.004 & 0.006 & 0.016 & 0.018 & 0.026 \\
\hline \multicolumn{8}{|l|}{ Cropping system (CS) } \\
\hline 2 & 0.004 & 0.002 & $0.017^{*}$ & 0.013 & 0.004 & 0.010 & \\
\hline TxCS & 10 & $0.012^{*}$ & 0.010 & 0.004 & 0.004 & 0.006 & 0.008 \\
\hline Error (b) & 60 & 0.005 & 0.006 & 0.004 & 0.006 & 0.009 & 0.009 \\
\hline
\end{tabular}

a $\mathrm{CC}=$ continuous corn, $\mathrm{SB}-\mathrm{C}=$ soybean-corn, $\mathrm{CSB}=$ continuous soybean.

*** Significant at the 0.001 probability levels.

** Significant at the 0.01 probability levels.

* Significant at the 0.05 probability levels. +Significant at the 0.10 probability levels.

at $113 \mathrm{~kg} \mathrm{~N} \mathrm{ha}^{-1}$ as ammonium nitrate at about the $\mathrm{V} 3$ growth stage. Other plant nutrients were within acceptable levels for corn and soybean production.

Corn and soybean were harvested after reaching physiological maturity. Prior to 1998, yield was determined by hand collecting all ears from an area of at least $9.3 \mathrm{~m}^{2}$ within each corn plot. Grain was removed from the ears, weighed, and sampled for water content. During this period soybean yield was determined by collecting all plants from an area of at least $4.6 \mathrm{~m}^{2}$. Plant samples were air-dried and grain threshed from stover. Grain was weighed and sampled for water content. Since 1998, both corn and soybean grain was harvested with a plot combine to determine yield. Three central rows of each plot were sampled. All yield data were adjusted to a standard moisture content of $155 \mathrm{~g} \mathrm{~g}^{-1} \mathrm{~kg}^{-1}$ for corn and $130 \mathrm{~g}^{-1} \mathrm{~kg}^{-1}$ for soybean.
Soil samples have been collected at various times over the duration of the experiment, but in some cases not all treatments or replications were sampled and in many cases the soil samples that were collected were not archived. In addition, few if any of these soil samples were taken from below $30-\mathrm{cm}$. This approach was changed in the late 1990s and soil samples were collected from the entire rooting profile to a depth of $150-\mathrm{cm}$. These samples were collected in the fall of 1999 after the crops had been harvested and before fall tillage. Four $3.1-\mathrm{cm}$ diameter cores were taken from all of the tillage and cropping system plots in all 6 replications with Giddings hydraulic probes to a depth of $150-\mathrm{cm}$ and divided into $0-15-$, 15-30-, 30-60-, 60-90-, 90-120-, and 120-150-cm increments and composited by depth. Soil bulk density was determined by using the volume and dry weights (dried at $105^{\circ} \mathrm{C}$ ) from the four sample cores from each subplot. All samples were

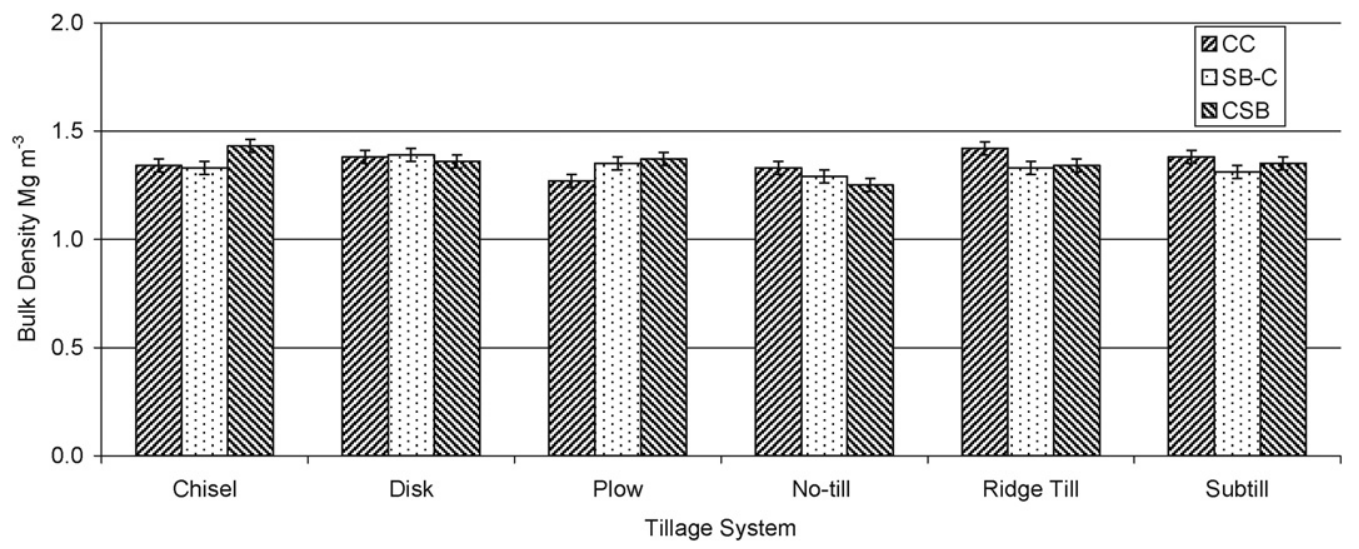

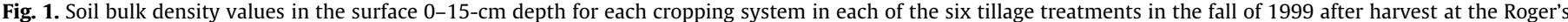

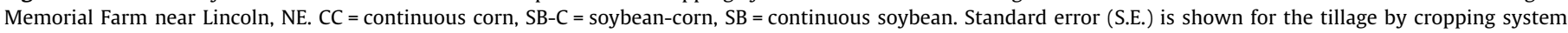
$(\mathrm{T} \times \mathrm{CS})$ interaction. 
Table 2

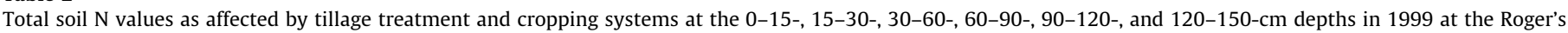
Memorial Farm near Lincoln, NE.

\begin{tabular}{|c|c|c|c|c|c|c|c|}
\hline \multirow[t]{3}{*}{ Tillage } & & \multicolumn{6}{|c|}{ Depth $(\mathrm{cm})$} \\
\hline & & $0-15$ & $15-30$ & $30-60$ & $60-90$ & $90-120$ & $120-150$ \\
\hline & & \multicolumn{6}{|c|}{ Total soil $\mathrm{N}\left(\mathrm{Mgha}^{-1}\right)$} \\
\hline Chisel & & 2.68 & 2.06 & 2.55 & 1.67 & 1.61 & 1.14 \\
\hline Disk & & 3.22 & 2.54 & 3.66 & 2.90 & 2.59 & 1.96 \\
\hline Plow & & 2.90 & 2.53 & 3.05 & 2.06 & 1.98 & 1.60 \\
\hline No-till & & 3.33 & 2.83 & 3.97 & 2.79 & 2.36 & 1.76 \\
\hline Ridge till & & 3.09 & 2.52 & 3.32 & 2.32 & 2.13 & 1.65 \\
\hline Subtill & & 3.01 & 2.43 & 3.56 & 2.84 & 2.53 & 1.95 \\
\hline \multirow[t]{6}{*}{ S.E. } & & 0.08 & 0.09 & 0.13 & 0.10 & 0.10 & 0.12 \\
\hline & \multicolumn{7}{|c|}{ Cropping system $^{a}$} \\
\hline & $\mathrm{CC}$ & 3.25 & 2.57 & 3.52 & 2.48 & 2.16 & 1.72 \\
\hline & SB-C & 3.02 & 2.50 & 3.40 & 2.48 & 2.21 & 1.63 \\
\hline & CSB & 2.85 & 2.38 & 3.13 & 2.33 & 2.23 & 1.69 \\
\hline & S.E. & 0.06 & 0.06 & 0.09 & 0.07 & 0.07 & 0.09 \\
\hline Source of variation & df & \multicolumn{6}{|c|}{ Mean squares } \\
\hline Replication & 5 & $2.77^{* * *}$ & $5.54^{* * *}$ & $29.58^{* * *}$ & $25.61^{* * *}$ & $15.88^{* * *}$ & $7.59^{* * *}$ \\
\hline Tillage(T) & 5 & 0.99 & $1.11^{*}$ & $4.53^{*}$ & $4.44^{*}$ & 2.48 & $1.65^{*}$ \\
\hline Error (a) & 25 & 0.45 & 0.30 & 1.36 & 1.65 & 1.60 & 0.71 \\
\hline \multicolumn{8}{|c|}{ Cropping system (CS) } \\
\hline 2 & $1.47^{* * *}$ & 0.33 & $1.48^{* *}$ & 0.27 & 0.05 & 0.07 & \\
\hline TxCS & 10 & 0.09 & 0.16 & 0.38 & 0.07 & 0.10 & 0.17 \\
\hline Error (b) & 60 & 0.11 & 0.13 & 0.28 & 0.20 & 0.17 & 0.27 \\
\hline
\end{tabular}

a $\mathrm{CC}=$ continuous corn, $\mathrm{SB}-\mathrm{C}=$ soybean-Corn, $\mathrm{CSB}=$ continuous soybean.

*** Significant at the 0.001 probability levels.

** Significant at the 0.01 probability levels.

Significant at the 0.05 probability levels.

air-dried, ground to pass a $2 \mathrm{~mm}$ screen, then further ground on a roller mill to pass a $0.106 \mathrm{~mm}$ sieve, and then analyzed for total $\mathrm{N}$ and $\mathrm{C}$ using an automatic CN analyzer, a Carlo Erba Model 1500 CNS Analyzer (Carlo Erba Strumentazione, Milan, Italy) interfaced with a continuous-flow mass spectrometer (Europa Scientific Limited, Crewe, England) according to the method described by Schepers et al. (1989). Total C equated to soil organic carbon (SOC) as all soils were at a $\mathrm{pH}$ of 7 or lower.

Total soil $\mathrm{N}$ and SOC values were calculated for each tillage treatment and cropping system combination at all depths and these values were then summed to determine total soil $\mathrm{N}$ and SOC reserves in the 0-30-, 0-60-, 0-90-, 0-120-, and 0-150-cm depths. Total soil $\mathrm{N}$ and SOC values were also calculated for each tillage and cropping system combination in "equivalent masses" of soil according to the methods described by Ellert and Bettany (1995). All statistical analyses were performed using Proc GLM in PC Version 9.1 of the Statistical Analyses System for Windows (SAS Institute, 2003).

\section{Results and discussion}

Soil bulk density results from soil samples taken in 1999 are shown in Table 1 . Bulk density values differed among tillage treatments and among cropping systems only in the $30-60-\mathrm{cm}$ depth (Table 1). In general, the differences were small and similar to results reported by Varvel and Wilhelm (2010) for soil samples collected from the 0 to $30-\mathrm{cm}$ depth in 2004 from this same experiment. A significant tillage treatment by cropping system interaction on bulk density values in the surface $0-15-\mathrm{cm}$ depth was obtained (Table 1 ). In the chisel and no-till tillage treatments, bulk density values were the least in CC and greatest in CSB cropping systems, whereas in the other four tillage treatments, bulk density values were greatest in CC and generally the least in the CSB cropping systems, which probably resulted in the significant interaction (Fig. 1). Overall, the small bulk density differences are probably as much due to the fact that the soil samples were collected in the fall of 1999, after the soils had reconsolidated during the growing season and prior to any tillage.

Total soil $\mathrm{N}$ results for all of the depth increments sampled in 1999 are shown in Table 2 . Soil N sampled in 1999 differed among tillage treatments in the 15-30-, 30-60-, 60-90-, and 120-150$\mathrm{cm}$ depths and among cropping systems in the 0-15- and 30-60$\mathrm{cm}$ depths (Table 2). Soil N values tended to be greatest in no-till and disk treatments compared to chisel and plow treatments (Table 2). Significant differences in soil $\mathrm{N}$ values among cropping systems in the $0-15$ - and $30-60-\mathrm{cm}$ depths were obtained because they were greatest in CC and least in CSB with those for SB-C generally intermediate in most of the tillage treatments (Table 2). These results are probably reflective of the differing amounts of both above and below ground biomass returned among these three cropping systems during the 14 years they have been in place in this experiment. Although total biomass yields were not reported, grain yields reported by Wilhelm and Wortmann (2004) from this experiment would be a good indication. They reported the greatest amount of grain biomass in CC and least in CSB, with that from the 2-year SB-C cropping system intermediate. These grain yields would translate to similar amounts of stover biomass production in those same systems as calculated by using harvest index values for corn and soybean presented by Johnson et al. (2006a).

Total SOC results in all of the depth increments sampled are presented in Table 3. Soil organic C values were significantly different among both tillage treatments and cropping systems in the 0-7.5-, 15-30-, and 30-60-cm depths (Table 3). Similar to the soil $\mathrm{N}$ results (Table 2 ), SOC values were greatest in those tillage treatments with the least amount of soil disturbance (e.g., no-till and disk) and least in those with more soil disturbance (e.g., plow)(Table 3). Also, SOC values were greatest in the CC and least in CSB with those in SB-C intermediate at these three depths (Table 3). Again, these results are probably a reflection of the differing amounts of biomass returned over the past 14 years by these three different cropping systems. Varvel and Wilhelm (2008) 
Table 3

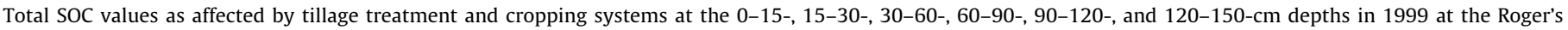
Memorial Farm near Lincoln, NE.

\begin{tabular}{|c|c|c|c|c|c|c|c|}
\hline \multirow[t]{3}{*}{ Tillage } & & \multicolumn{6}{|c|}{ Depth $(\mathrm{cm})$} \\
\hline & & $0-15$ & $15-30$ & $30-60$ & $60-90$ & $90-120$ & $120-150$ \\
\hline & & \multicolumn{6}{|c|}{ Total SOC $\left(\mathrm{Mg} \mathrm{ha}^{-1}\right)$} \\
\hline Chisel & & 33.3 & 24.0 & 27.4 & 15.3 & 12.9 & 9.8 \\
\hline Disk & & 34.9 & 26.6 & 37.3 & 27.1 & 21.6 & 13.6 \\
\hline Plow & & 31.8 & 28.3 & 28.6 & 17.1 & 14.8 & 11.0 \\
\hline No-till & & 37.7 & 31.3 & 41.5 & 27.2 & 21.0 & 12.6 \\
\hline Ridge till & & 36.3 & 30.0 & 38.2 & 24.6 & 18.8 & 12.6 \\
\hline Subtill & & 32.4 & 26.7 & 36.4 & 27.7 & 21.9 & 14.3 \\
\hline \multirow[t]{6}{*}{ S.E. } & & 0.6 & 0.7 & 0.9 & 0.8 & 0.8 & 0.5 \\
\hline & \multicolumn{7}{|c|}{ Cropping system $^{\mathrm{a}}$} \\
\hline & $\mathrm{CC}$ & 36.6 & 28.6 & 36.1 & 22.6 & 18.4 & 12.1 \\
\hline & SB-C & 34.1 & 28.0 & 35.6 & 23.6 & 18.6 & 12.1 \\
\hline & CSB & 32.5 & 26.8 & 33.0 & 23.3 & 18.5 & 12.7 \\
\hline & S.E. & 0.4 & 0.5 & 0.6 & 0.5 & 0.5 & 0.4 \\
\hline Source of variation & df & \multicolumn{6}{|c|}{ Mean squares } \\
\hline Replication & 5 & 132.6 & $533.7^{* 4.4}$ & 5039.8 & 4462.4 & $2363.8^{*+1+4}$ & $725.7^{*+1}$ \\
\hline Tillage $(\mathrm{T})$ & 5 & $94.7^{* *}$ & $123.4^{* * *}$ & $572.1^{*}$ & 548.2 & 261.8 & 48.7 \\
\hline Error (a) & 25 & 23.6 & 20.6 & 239.3 & 395.1 & 247.7 & 61.2 \\
\hline \multicolumn{8}{|l|}{ Cropping system (CS) } \\
\hline 2 & $152.6^{* * *}$ & $30.3^{*}$ & $103.6^{* * *}$ & 9.4 & 0.5 & 4.6 & \\
\hline TxCS & 10 & 3.9 & 4.7 & 8.9 & 8.9 & 12.3 & $8.8^{+}$ \\
\hline Error (b) & 60 & 6.4 & 8.0 & 13.0 & 8.9 & 10.9 & 5.0 \\
\hline
\end{tabular}

a $\mathrm{CC}=$ Continuous corn, $\mathrm{SB}-\mathrm{C}=$ soybean-corn, $\mathrm{CSB}=$ continuous soybean.

**** Significant at the 0.001 probability levels.

** Significant at the 0.01 probability levels.

Significant at the 0.05 probability levels.

reported similar results from an irrigated experiment with the same three cropping systems.

Total soil $\mathrm{N}$ and SOC to various sampled depths in the profile were also determined and those results are presented in Tables 4 and 5 . Soil N values were significantly different between tillage treatments and cropping systems at all of the depth profiles (Table 4) and SOC values were significantly different between tillage treatments in the 0-30-, 0-60-, and 0-90-cm profiles and between cropping systems at all of the depth profiles (Table 5). These results contrast those presented by Angers et al. (1997), where they found no differences in total soil $\mathrm{N}$ and SOC between no-till and plow tillage treatments to a $60-\mathrm{cm}$ depth in cool, humid soils in eastern Canada. In their experiment, they found significant differences between soil $\mathrm{N}$ and SOC only in the surface $10-\mathrm{cm}$, but the plow treatment in their study had greater soil $\mathrm{N}$ and SOC than no-till at the $20-40-\mathrm{cm}$ depth. They suggested that conclusions about total soil $\mathrm{N}$ and SOC gains or losses in long-term tillage or cropping systems should be based on samples taken well beyond the deepest tillage depth. Our results indicate that differences in total soil $\mathrm{N}$ and SOC were indeed obtained in the surface zones (Tables 2 and 3), but we also obtained significant differences throughout the profile (Tables 4 and 5).

For comparison we also used the approach presented by Ellert and Bettany (1995) to calculate total soil $\mathrm{N}$ and $\mathrm{C}$ in equivalent masses of soil. Their method is presented as a way to ensure that comparisons made under contrasting management systems are made between equivalent soil masses. Using this approach removes the bias that occurs when samples are collected from experiments under various management scenarios to so-called predefined depths. Results from samples collected to certain depths are compared as we have done in Tables 2-5, but as Ellert and Bettany (1995) state, the masses of these sampled depths often differ greatly because of the effects or lack of tillage. Total soil $\mathrm{N}$ and $S O C$ results from this study using their approach are presented in Tables 6 and 7. These results are very similar to those presented in Tables 4 and 5 in that total soil $\mathrm{N}$ values are significantly different between tillage treatments and cropping systems in all 3 equivalent masses of soil (Table 6) and total SOC values are significantly different between tillage treatments in the upper 2 equivalent masses of soil and between cropping systems in all 3 equivalent masses (Table 7). The similarity in these results would tend to be expected as the total soil $\mathrm{N}$ and SOC values in soil masses compared in Tables 6 and 7 (9000-, 13,000-, and 19,000-Mg ha ${ }^{-1}$ ) are approximately equivalent to some of the depths compared in Tables 4 and $5(0-60-, 0-90-$, and $0-120-\mathrm{cm})$. Their similarity is further substantiated by paired regressions between the total soil $\mathrm{N}$ and SOC at each depth with the approximate equivalent mass of soil. These regressions all had $R^{2}$ values of 0.99 and greater, indicative of very strong correlations between the total soil $\mathrm{N}$ and SOC values by depth and equivalent mass.

\section{Summary}

Total soil N and SOC results presented above from this longterm tillage and cropping system experiment are very interesting and unique because they demonstrate both significant differences at individual sampled depths but also at cumulative depths in the profile (Tables 2-7). Also, the lack of any significant tillage treatment by cropping system interactions indicated that total soil $\mathrm{N}$ and SOC amounts accumulated or lost by each of the cropping systems was consistent across tillage treatments (Tables 2-7). As mentioned above, total soil $\mathrm{N}$ and SOC levels were greatest in CC and least in CSB with those in SB-C intermediate both in individual sampled depths and in cumulative depths in the profile across all tillage treatments (Tables 2-7).

Although the results presented above indicate significant differences in total soil $\mathrm{N}$ and SOC levels were obtained from this study in 1999, it is difficult to ascertain whether these soil $\mathrm{N}$ and SOC levels are indicative of changes since the inception of the experiment in 1980. As mentioned by Varvel and Wilhelm (2010), soil samples taken at the beginning of this long-term study were not archived nor were they analyzed for organic matter, total N, or SOC. Varvel and Wilhelm (2010) presented results from surface samples $(0-30-\mathrm{cm})$ collected from this same experiment in 2004. Their results demonstrated the same 
Table 4

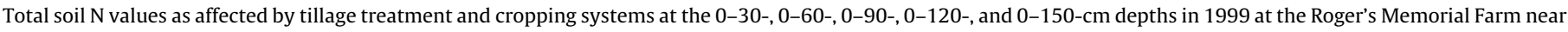
Lincoln, NE.

\begin{tabular}{|c|c|c|c|c|c|c|}
\hline \multirow[t]{3}{*}{ Tillage } & & \multicolumn{5}{|c|}{ Depth $(\mathrm{cm})$} \\
\hline & & $0-30$ & $0-60$ & $0-90$ & $0-120$ & $0-150$ \\
\hline & & \multicolumn{5}{|c|}{ Total soil $\mathrm{N}\left(\mathrm{Mg} \mathrm{ha}^{-1}\right)$} \\
\hline Chisel & & 4.73 & 7.28 & 8.96 & 10.57 & 11.71 \\
\hline Disk & & 5.76 & 9.41 & 12.31 & 14.90 & 16.86 \\
\hline Plow & & 5.42 & 8.47 & 10.53 & 12.51 & 14.11 \\
\hline No-till & & 6.16 & 10.13 & 12.92 & 15.28 & 17.05 \\
\hline Ridge till & & 5.61 & 8.93 & 11.25 & 13.38 & 15.03 \\
\hline Subtill & & 5.44 & 9.00 & 11.83 & 14.36 & 16.31 \\
\hline \multirow[t]{6}{*}{ S.E. } & & 0.13 & 0.20 & 0.26 & 0.31 & 0.36 \\
\hline & \multicolumn{6}{|c|}{ Cropping system $^{a}$} \\
\hline & $\mathrm{CC}$ & 5.82 & 9.34 & 11.81 & 13.97 & 15.69 \\
\hline & SB-C & 5.52 & 8.92 & 11.40 & 13.62 & 15.25 \\
\hline & CSB & 5.22 & 8.35 & 10.68 & 12.91 & 14.60 \\
\hline & S.E. & 0.09 & 0.14 & 0.19 & 0.22 & 0.26 \\
\hline Source of variation & df & \multicolumn{5}{|c|}{ Mean squares } \\
\hline Replication & 5 & $15.73^{* * *}$ & $82.06^{* * *}$ & $193.71^{* * *}$ & $319.13^{* * *}$ & $423.48^{* * *}$ \\
\hline Tillage $(\mathrm{T})$ & 5 & $4.01^{*}$ & $16.51^{* *}$ & $36.06^{* *}$ & $55.71^{*}$ & $74.96^{*}$ \\
\hline Error (a) & 25 & 1.18 & 3.47 & 8.50 & 16.49 & 23.16 \\
\hline \multicolumn{7}{|c|}{ Cropping system (CS) } \\
\hline 2 & $3.15^{* * *}$ & $8.84^{* * *}$ & $11.85^{* * *}$ & $10.56^{* *}$ & $10.88^{*}$ & \\
\hline TxCS & 10 & 0.20 & 1.02 & 1.11 & 1.34 & 2.02 \\
\hline Error (b) & 60 & 0.31 & 0.72 & 1.25 & 1.75 & 2.39 \\
\hline
\end{tabular}

${ }^{\mathrm{a}} \mathrm{CC}=$ continuous corn, $\mathrm{SB}-\mathrm{C}=$ soybean-corn, $\mathrm{CSB}=$ Continuous soybean.

*** Significant at the 0.001 probability levels.

** Significant at the 0.01 probability levels.

* Significant at the 0.05 probability levels.

significant differences due to tillage treatments and cropping systems on SOC and total N as found in this study. Furthermore, when compared to results from samples collected from a limited set of treatments sampled in 1989, it appeared SOC was being sequestered.
Based on those assumptions, we examined the results from our samples from only the 0-30-cm depth taken in 1999 and then compared them to data presented by Varvel and Wilhelm (2010). These results indicated that the total SOC levels obtained in the 0 $30-\mathrm{cm}$ depth in 1999 reported here (Table 3) were the same as or

Table 5

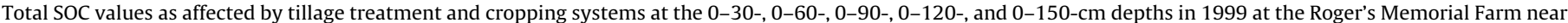
Lincoln, NE.

\begin{tabular}{|c|c|c|c|c|c|c|}
\hline \multirow[t]{3}{*}{ Tillage } & & \multicolumn{5}{|l|}{ Depth $(\mathrm{cm})$} \\
\hline & & $0-30$ & $0-60$ & $0-90$ & $0-120$ & $0-150$ \\
\hline & & \multicolumn{5}{|c|}{ Total soil C $\left(\mathrm{Mg} \mathrm{ha}^{-1}\right)$} \\
\hline Chisel & & 57.33 & 84.71 & 100.02 & 112.89 & 122.73 \\
\hline Disk & & 61.45 & 98.74 & 125.84 & 147.41 & 161.01 \\
\hline Plow & & 60.10 & 88.70 & 105.81 & 120.62 & 131.61 \\
\hline No-till & & 68.98 & 110.51 & 137.67 & 158.67 & 171.22 \\
\hline Ridge till & & 66.23 & 104.41 & 128.99 & 147.81 & 160.37 \\
\hline Subtill & & 59.10 & 95.51 & 123.21 & 145.13 & 159.40 \\
\hline \multirow[t]{6}{*}{ S.E. } & & 1.00 & 1.48 & 1.86 & 2.16 & 2.34 \\
\hline & \multicolumn{6}{|c|}{ Cropping system $^{a}$} \\
\hline & $\mathrm{CC}$ & 65.21 & 101.35 & 123.94 & 142.34 & 154.46 \\
\hline & SB-C & 62.07 & 97.66 & 121.23 & 139.86 & 151.92 \\
\hline & CSB & 59.31 & 92.28 & 115.60 & 134.07 & 146.78 \\
\hline & S.E. & 0.71 & 1.05 & 1.31 & 1.53 & 1.65 \\
\hline Source of variation & df & \multicolumn{5}{|c|}{ Mean squares } \\
\hline Replication & 5 & $1181.27^{* * *}$ & $10566.10^{* * *}$ & $28197.32^{* * *}$ & $46366.54^{* * *}$ & $58462.00^{* *}$ \\
\hline Tillage $(\mathrm{T})$ & 5 & $361.90^{* * *}$ & $1665.23^{* *}$ & $3735.53^{*}$ & 5730.49 & 6634.12 \\
\hline Error (a) & 25 & 64.87 & 354.46 & 1393.41 & 2750.92 & 3598.74 \\
\hline \multicolumn{7}{|l|}{ Cropping system (CS) } \\
\hline 2 & $314.21^{* * *}$ & $750.24^{* * *}$ & $651.47^{* * *}$ & $648.40^{* * *}$ & $551.02^{* * *}$ & \\
\hline TxCS & 10 & 2.78 & 10.50 & 25.04 & 57.79 & 74.50 \\
\hline Error (b) & 60 & 17.92 & 39.40 & 62.13 & 84.30 & 98.53 \\
\hline
\end{tabular}

a $\mathrm{CC}=$ continuous corn, $\mathrm{SB}-\mathrm{C}=$ soybean-corn, $\mathrm{CSB}=$ continuous soybean .

*** Significant at the 0.001 probability levels.

** Significant at the 0.01 probability levels.

* Significant at the 0.05 probability levels. 
Table 6

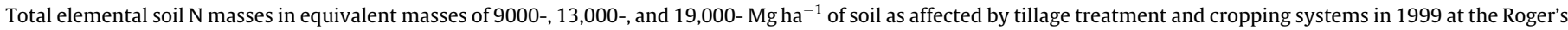
Memorial Farm near Lincoln, NE.

\begin{tabular}{|c|c|c|c|c|}
\hline \multirow[t]{3}{*}{ Tillage } & & \multicolumn{3}{|c|}{ Equivalent soil mass $\left(\mathrm{Mg} \mathrm{ha}^{-1}\right)$} \\
\hline & & 9000 & 13,000 & 19,000 \\
\hline & & \multicolumn{3}{|c|}{ Elemental mass of soil $\mathrm{N}\left(\mathrm{Mg} \mathrm{ha}^{-1}\right)$} \\
\hline Chisel & & 7.28 & 8.71 & 10.62 \\
\hline Disk & & 9.60 & 12.23 & 15.44 \\
\hline Plow & & 8.65 & 10.40 & 12.85 \\
\hline No-till & & 10.48 & 12.97 & 15.99 \\
\hline Ridge till & & 9.25 & 11.20 & 13.79 \\
\hline Subtill & & 9.31 & 11.84 & 14.98 \\
\hline \multirow[t]{6}{*}{ S.E. } & & 0.20 & 0.25 & 0.32 \\
\hline & Cropp & & & \\
\hline & $\mathrm{CC}$ & 9.52 & 11.66 & 14.37 \\
\hline & SB-C & 9.18 & 11.35 & 14.09 \\
\hline & CSB & 8.59 & 10.66 & 13.38 \\
\hline & S.E. & 0.14 & 0.18 & 0.23 \\
\hline Source of variation & $\mathrm{df}$ & \multicolumn{3}{|c|}{ Mean squares } \\
\hline Replication & 5 & $96.86^{* * *}$ & $216.95^{* * *}$ & $387.78^{* * *}$ \\
\hline Tillage $(\mathrm{T})$ & 5 & $20.60^{* *}$ & $41.25^{* *}$ & $71.25^{*}$ \\
\hline Error (a) & 25 & 3.96 & 9.81 & 21.56 \\
\hline Cropping System (CS) & 2 & $7.98^{* * * *}$ & $9.40^{* * *}$ & $9.29^{* *}$ \\
\hline TxCS & 10 & 0.91 & 0.94 & 1.29 \\
\hline Error (b) & 60 & 0.72 & 1.11 & 1.82 \\
\hline
\end{tabular}

a $\mathrm{CC}=$ continuous corn, $\mathrm{SB}-\mathrm{C}=$ soybean-corn, $\mathrm{CSB}=$ continuous soybean.

**** Significant at the 0.001 probability levels.

** Significant at the 0.01 probability levels.

"Significant at the 0.05 probability levels.

slightly less than those from 2004 (33.7-, 36.2-, 31.8-, 38.8-, 36.0-, and 33.6-Mg SOC ha ${ }^{-1}$ in the Chisel, Disk, Plow, No-till, Ridge Till, and Subtill treatments, respectively) reported in Varvel and Wilhelm (2010). Since only total SOC results were available from 2004 , our conclusions will pertain to SOC only. It appears that total SOC has been sequestered in this experiment, especially in the notill treatments as those levels have increased from 1999 to 2004. It also appears that given these positive results over this five $\mathrm{yr}$ period that SOC values have probably been increasing over the entire duration of this experiment, especially in the no-till treatment (Fig. 2).

The most important and perhaps more significant results from this paper are those related to significant changes in total soil $\mathrm{N}$ and SOC both in the surface $0-15-$ or $15-30-\mathrm{cm}$ depths as reported earlier, but also at depths greater than $30-\mathrm{cm}$ (Tables 2-7). Our results agree with those of other researchers including Angers et al. (1997),

Table 7

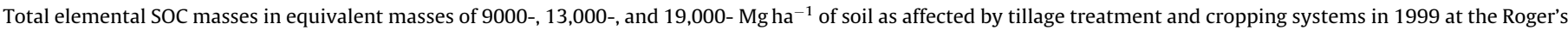
Memorial Farm near Lincoln, NE.

\begin{tabular}{|c|c|c|c|c|}
\hline \multirow[t]{3}{*}{ Tillage } & & \multicolumn{3}{|c|}{ Equivalent soil mass $\left(\mathrm{Mg} \mathrm{ha}^{-1}\right)$} \\
\hline & & 9000 & 13,000 & 19,000 \\
\hline & & \multicolumn{3}{|c|}{ Elemental mass of SOC $\left(\mathrm{Mg} \mathrm{ha}^{-1}\right)$} \\
\hline Chisel & & 84.93 & 97.79 & 113.63 \\
\hline Disk & & 100.90 & 126.07 & 153.38 \\
\hline Plow & & 90.45 & 104.82 & 123.33 \\
\hline No-till & & 114.39 & 138.55 & 165.40 \\
\hline Ridge till & & 108.22 & 128.95 & 151.70 \\
\hline Subtill & & 99.31 & 124.50 & 151.93 \\
\hline \multirow[t]{6}{*}{ S.E. } & & 1.50 & 1.81 & 2.30 \\
\hline & \multicolumn{4}{|c|}{ Cropping system $^{a}$} \\
\hline & $\mathrm{CC}$ & 103.45 & 123.19 & 146.36 \\
\hline & SB-C & 100.64 & 121.21 & 144.45 \\
\hline & $\mathrm{CSB}$ & 95.02 & 115.93 & 138.88 \\
\hline & S.E. & 1.06 & 1.28 & 1.63 \\
\hline Source of variation & df & \multicolumn{3}{|l|}{ Mean squares } \\
\hline Replication & 5 & $13168.59^{* * *}$ & $32775.2^{* * *}$ & $58189.8^{* * *}$ \\
\hline Tillage $(\mathrm{T})$ & 5 & $2137.05^{* *}$ & $4337.6^{*}$ & 7252.0 \\
\hline Error (a) & 25 & 455.37 & 1720.5 & 3740.9 \\
\hline Cropping System (CS) & 2 & $662.81^{* * *}$ & $506.2^{* * *}$ & $544.7^{* *}$ \\
\hline TxCS & 10 & 22.66 & 39.0 & 76.2 \\
\hline Error (b) & 60 & 40.59 & 59.26 & 95.63 \\
\hline
\end{tabular}

a $\mathrm{CC}=$ continuous corn, $\mathrm{SB}-\mathrm{C}=$ soybean-corn, $\mathrm{CSB}=$ continuous soybean.

**** Significant at the 0.001 probability levels.

** Significant at the 0.01 probability levels.

"Significant at the 0.05 probability levels. 


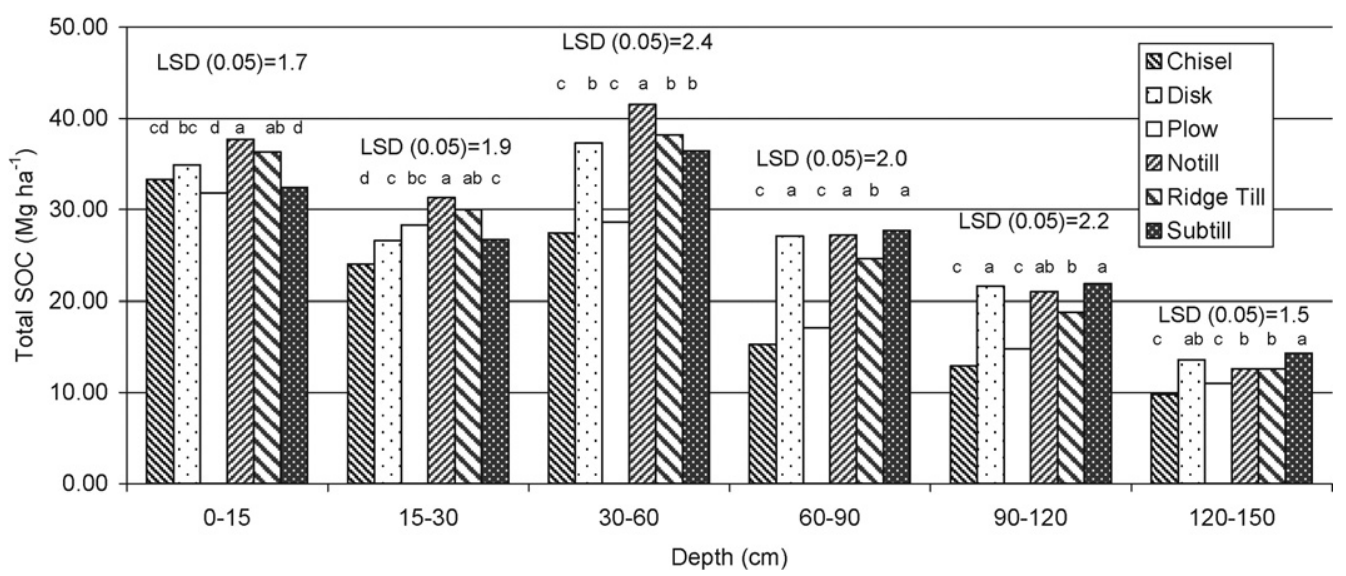

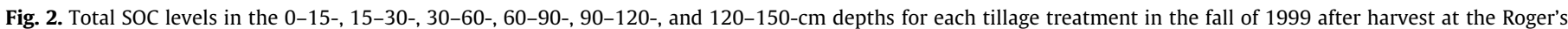


significantly different from each other $(P<0.05)$.

Angers and Eriksen-Hamel (2008), Edwards et al. (1988), and West and Post (2002) in their review of published studies that the adoption of no-till leads to an accumulation of SOC at or near the soil surface, but in addition to their findings, we also found significant SOC accumulations below $30-\mathrm{cm}$ in most of the tillage treatments compared in our study including no-till (Tables 2-7). Our results in the plow tillage treatment (full inversion tillage as designated by Angers and Eriksen-Hamel (2008)) did show an accumulation of SOC in the 15-30-cm depth similar to those reported by these researchers, but it was not as great as that obtained with no-till (Fig. 2). Our results also show accumulations of soil N (Table 2) and SOC at greater depths in the profile (Fig. 2), especially in those treatments which would be considered as some form of conservation tillage.

The results from this long-term study indicated significant differences in soil $\mathrm{N}$ and SOC were obtained among 6 tillage treatments with 3 cropping systems both at individual depths and in total soil profiles (Tables 2-7). It appeared that soil $\mathrm{N}$ and SOC levels have increased in most if not all of these tillage treatments, but without initial soil $\mathrm{N}$ and SOC levels it cannot be stated unequivocally. These results compared to those reported by Varvel and Wilhelm (2010) for changes in the surface $0-30-\mathrm{cm}$ indicated that SOC levels have been increased during the past $20+$ years in this study, but the actual magnitude of those changes is difficult to determine. It is possible that soil $\mathrm{N}$ and SOC levels have actually decreased in some of these tillage treatment and cropping systems, but again that remains to be determined. The results do indicate large differences in the amounts of soil $\mathrm{N}$ and SOC in both tillage treatments and cropping systems are present after $15+$ years in this study. These data also indicate that these amounts are greatest in no-till and reduced tillage treatments with a CC cropping system and least in plow and chisel tillage treatments with a CSB cropping system at most sampling depths in the profile (Fig. 2). These results demonstrate that using conservation tillage has improved soil $\mathrm{N}$ and SOC in all of the cropping systems in this study and indicates a good potential for improved soil quality and increased sustainability. In addition, as stated by Angers and Ericksen-Hamel (2008), soil N and SOC accumulated at the deeper depths in the profile may be more stable and less susceptible to loss if the surface soil is tilled or disturbed in some manner.

\section{Acknowledgements}

The corresponding author would especially like to thank his coauthor, Dr. Wally Wilhelm who passed away in the fall of 2008 from pancreatic cancer, for his unending enthusiasm and continual optimism throughout our many joint projects during the past 25 years.
I would also like to thank Lloyd Mielke for having the foresight to initiate this study in 1980 and to Wally for taking over and continuing it after Lloyd retired. Thanks are due also to the numerous scientists, technicians, and graduate students who have helped maintain and sample these plots over the past 30 years.

This publication is based upon work supported by the Agricultural Research Service under the GRACEnet Project.

\section{References}

Angers, D.A., Bolinder, M.A., Carter, M.R., Gregorich, E.G., Drury, C.F., Liang, B.C., Voroney, R.P., Simard, R.R., Donald, R.G., Beuaert, R.P., Martel, J., 1997. Impact of tillage practices on organic carbon storage in cool, humid soils of eastern Canada. Soil Till. Res. 41, 191-201.

Angers, D.A., Eriksen-Hamel, N.S., 2008. Full-inversion tillage and organic carbon distribution in soil profiles: a meta-analysis. Soil Sci. Soc. Am. J. 72, 1370-1374.

Brejda, J.J., Moorman, T.B., Karlen, D.L., Dao, T.H., 2000. Identification of regional soil quality factors and indicators: I. Central and Southern high plains. Soil Sci. Soc. Am. J. 64, 2115-2124.

Edwards, W.M., Shipitalo, M.J., Norton, L.D., 1988. Contribution of macroporosity to infiltration into a continuous corn no-tilled watershed: implications for contaminant movement. J. Contam. Hydrol. 3, 193-205.

Ellert, B.H., Bettany, J.R., 1995. Calculation of organic matter and nutrients stored in soils under contrasting management regimes. Can. J. Soil Sci. 75, 529-538.

Gal, A., Vyn, T.J., Michéli, E., Kladivko, E.J., McFee, W.W., 2007. Soil carbon and nitrogen accumulation with long-term no-till versus moldboard plowing overestimated with tilled-zone sampling depths. Soil Till. Res. 96, 42-51.

Johnson, J.M.F., Allmaras, R., Reicosky, D., 2006a. Estimating source carbon from crop residues, roots, and rhizodeposits using the national grain-yield database. Agron. J. 98, 622-636.

Johnson, J.M.F., Reicosky, D., Allmaras, R., Archer, D., Wilhelm, W.W., 2006b. A matter of balance: conservation and renewable energy. J. Soil Water Conserv. $61,120 \mathrm{~A}-125 \mathrm{~A}$.

Lal, R., 2004. Is crop residue a waste? J. Soil Water Conserv. 59, 136A-139A.

Pikul Jr., J.L., Johnson, J.M.F., Schumacher, T.E., Vigil, M., Riedell, W.E., 2008. Change in surface soil carbon under rotated corn in eastern South Dakota. Soil Sci. Soc. Am. J. 72, 1738-1744.

Ritchie, S.W., Hanway, J.J., Benson, G.O. 1986. How a corn plant develops. Special Report No. 48. Iowa State University of Science and Technology-Cooperative Extension Service, Ames, IA.

Ritchie, S.W., Hanway, J.J., Thompson, H.E., Benson, G.O. 1996. How a soybean plant develops. Special Report No. 53. Iowa State University of Science and Technology Cooperative Extension Service, Ames, IA

Institute, S.A.S., 2003. SAS/STAT User's Guide, Release 9. 1 ed. SAS Institute, Inc. Cary, NC.

Schepers, J.S., Francis, D.D., Thompson, M.T., 1989. Simultaneous determination of total C, total N, and $15 \mathrm{~N}$ on soil and plant material. Comm. Soil Sci. Plant Anal. 20, 949-959.

Towery, D., Werblow, S., 2010. Facilitating Conservation Farming Practices and Enhancing Environmental Sustainability with Agricultural Biotechnology. Conservation Information Technology Center.

Sparling, G.P., Wheeler, D., Vesely, E.T., Schipper, L.A., 2006. What is organic matter worth? J. Environ. Qual. 35, 548-557.

Varvel, G.E., 2006. Soil organic carbon changes in diversified rotations of the western Corn Belt. Soil Sci. Soc. Am. J. 70, 426-433.

Varvel, G.E., Wilhelm, W.W., 2008. Soil carbon levels in irrigated western Corn Belt rotations. Agron. J. 100, 1180-1184. 
Varvel, G.E., Wilhelm, W.W., 2010. Long-term soil organic carbon as affected by tillage and croppings systems. Soil Sci. Soc. Am. J. 74, 915-921.

West, T.O., Post, W.M., 2002. Soil organic carbon sequestration rates by tillage and crop rotation: a global data analysis. Soil Sci. Soc. Am. J. 66, 1930-1946.
Wilhelm, W.W., Johnson, J.M.F., Karlen, D.L., Lightle, D.T., 2007. Corn stover to sustain soil organic carbon further constrains biomass supply. Agron. J. 99, 1665-1667.

Wilhelm, W.W., Wortmann, C.S., 2004. Tillage and rotation interactions for corn and soybean grain yield as affected by precipitation and air temperature. Agron. J. 96, 425-432. 